\title{
User Experiences and Wellbeing at Work
}

\author{
Bhutkar, Ganesh; Roto, Virpi; Clemmensen, Torkil; Barricelli, Barbara Rita; Abdelnour- \\ Nocera, José; Meschtscherjakov, Alexander; Lopes, Arminda Guerra; Campos, Pedro; \\ Gonçalves, Frederica
}

\author{
Document Version \\ Accepted author manuscript
}

Published in:

Human-Computer Interaction - INTERACT 2019

DOI:

10.1007/978-3-030-29390-1_75

Publication date:

2019

\section{License \\ Unspecified}

Citation for published version (APA):

Bhutkar, G., Roto, V., Clemmensen, T., Barricelli, B. R., Abdelnour-Nocera, J., Meschtscheriakov, A., Lopes, A. G., Campos, P., \& Goncalves, F. (2019). User Experiences and Wellbeing at Work. In D. Lamas, F. Loizides, L. Nacke, H. Petrie, M. Winckler, \& P. Zaphiris (Eds.), Human-Computer Interaction - INTERACT 2019:

Proceedings of the 17th IFIP TC 13 International Conference, Part IV (pp. 754-758). Springer. Lecture Notes in Computer Science Vol. 11749 https://doi.org/10.1007/978-3-030-29390-1_75

Link to publication in CBS Research Portal

\section{General rights}

Copyright and moral rights for the publications made accessible in the public portal are retained by the authors and/or other copyright owners and it is a condition of accessing publications that users recognise and abide by the legal requirements associated with these rights.

\section{Take down policy}

If you believe that this document breaches copyright please contact us (research.lib@cbs.dk) providing details, and we will remove access to the work immediately and investigate your claim. 


\section{User Experiences and Wellbeing at Work}

\section{Ganesh Bhutkar, Virpi Roto, Torkil Clemmensen, Barbara Rita Barricelli, José Abdelnour-Nocera, Alexander Meschtscherjakov, Arminda Guerra Lopes, Pedro Campos, and Frederica Gonçalves}

Article in proceedings (Accepted version*)

\section{Please cite this article as:}

Bhutkar, G., Roto, V., Clemmensen, T., Barricelli, B. R., Abdelnour-Nocera, J., Meschtscherjakov, A., Lopes, A. G., Campos, P., \& Gonçalves, F. (२०19). User Experiences and Wellbeing at Work. In D. Lamas, F. Loizides, L. Nacke, H. Petrie, M. Winckler, \& P. Zaphiris (Eds.), Human-Computer Interaction - INTERACT 2019: Proceedings of the 17th IFIP TC 13 International Conference, Part IV (pp. 754-758). Springer. Lecture Notes in Computer Science, Vol.. 11749 https://doi.org/10.1007/978-3-030-29390-1_75

This is a post-peer-review, pre-copyedit version of an article published in Human-Computer Interaction INTERACT 2019: Proceedings of the 17th IFIP TC 13 International Conference, Part IV. The final authenticated version is available online at:

DOl: https://doi.org/10.1007/978-3-030-29390-1_75

* This version of the article has been accepted for publication and undergone full peer review but has not been through the copyediting, typesetting, pagination and proofreading process, which may lead to differences between this version and the publisher's final version AKA Version of Record. 


\title{
User Experiences and Wellbeing at Work
}

\author{
Ganesh Bhutkar $^{1}$, Virpi Roto ${ }^{2}$, Torkil Clemmensen ${ }^{3}$, Barbara Rita Barricelli ${ }^{4}$, \\ Jose Abdelnour-Nocera ${ }^{5}$, Alexander Meschtscherjakov ${ }^{6}$, Arminda Guerra Lopes ${ }^{7}$, \\ Pedro Campos ${ }^{8}$ and Frederica Gonçalves ${ }^{8}$ \\ ${ }^{1}$ Vishwakarma Institute of Technology (VIT) Pune, India \\ ${ }^{2}$ Aalto University, School of Arts, Design and Architecture, Finland \\ ${ }^{3}$ Copenhagen Business School, Denmark \\ ${ }^{4}$ Università degli Studi di Milano, Italy \\ ${ }^{5}$ University of West London, UK \\ ${ }^{6}$ Salzburg University, Austria \\ ${ }^{7}$ Instituto Politécnico de Castelo Branco, Portugal \\ ${ }^{8}$ University of Madeira, Portugal \\ ganesh.bhutkarevit.edu \& \\ virpi.rotodaalto.fi
}

\begin{abstract}
As digitalization pervades diverse types of workplaces, an increasing part of employees' work is with interactive technologies. Therefore, user experience of the technologies at work has an important influence to the job satisfaction, work motivation, and employee wellbeing. However, previous research on these topics rarely considers the digitalized work processes and the tools used at work. This workshop invites experts studying work with digital technologies to discuss the impact of these kind of tools on employee wellbeing. The UX@Work workshop aims to build a research agenda for tackling a multitude of overlooked research topics in this area.
\end{abstract}

Keywords: UX at work, User experience, Employee wellbeing, Work analysis.

\section{$1 \quad$ Topic}

Wellbeing of employees is an important challenge for today's organizations and companies. The mental and physical wellbeing of employees or staff can be assessed through a study of impact of user experiences at their workplaces $[1,3]$. Work efficiency and personal health are affected if the employee wellbeing is not maintained in the organization. It can also lead to employee absenteeism as well as reduced productivity at workplaces such as IT companies, banks, factories, hospitals or even the municipalities and cities. 
Use of digital technologies is an increasingly large part of the daily activities in most workplaces, thus an increasingly important part of wellbeing at work. User experiences ${ }^{1}$ with the digital tools may influence job satisfaction either positively or negatively and thereby affect employee wellbeing and work engagement. While many employers understand the importance of user experience of work tools in the big picture of employee wellbeing, tools for work context are still often selected based on price, performance, and security criteria, forgetting their emotional impacts on employees. Perhaps because of the slow waking up of the industry, there is surprisingly little research on work tool user experiences. After the early works about a decade ago $[2,4,6]$ only recently this topic has gained more momentum, e.g., a special issue on designing interactive systems for work engagement [5].

With the current set of still rather limited set of scientific literature, it is the right time to think about the topics that deserve more attention from scholars. UX@Work workshop aims to compile a research agenda for studying the role of interactive technologies at increasingly digitized workplaces as well as related Industry 4.0 scenarios.

\section{Objectives}

The UX@Work workshop has three main objectives:

1. To share the research needs on concepts, theories, practices and challenges related to user experiences and wellbeing in various work environments.

2. To compile a research agenda for future research in the area of user experiences and wellbeing at work.

3. To expand the IFIP TC13 WG6 Human Work Interaction Design community with researchers and practitioners from various disciplines and work environments.

\section{Expected Outcomes}

The workshop will produce a research agenda for studying design and impact of interactive technologies UX and employee wellbeing at work. A poster visualizing the research agenda will be compiled to be visible in the INTERACT posters session (if allowed by the Posters chairs). The extended versions of paper contributions at UX@Work workshop will be published as a Topical Collection of Quality and User Experience journal by Springer.

\footnotetext{
${ }^{1}$ A person's perceptions and responses that result from the use and/or anticipated use of a product, system or service, ISO 9241-210:2010
} 


\section{$4 \quad$ Target Audience}

The ideal target audience for UX@Work workshop includes researchers, academicians and practitioners working on topics related to user experiences, work analysis, interaction design, work environments, and/or staff wellbeing at work. We pay special attention to attracting practitioners from various work environments to discuss real-life case studies featuring user experiences and wellbeing at work. Early-stage researchers and $\mathrm{PhD}$ students are also invited to submit posters on their work-in-progress research in this area.

\section{$5 \quad$ Organizing Committee}

The UX@Work workshop is organized by IFIP TC13 WG13.6 - Human Work Interaction Design (HWID).

Ganesh Bhutkar is a Coordinator, Centre of Excellence in HCI, Vishwakarma Institute of Technology (VIT) Pune, India. He is Assistant Head (Research) at Department of Computer Engineering at VIT, Pune. His research work is mainly focused on HCI, Assistive Technologies and Medical Usability. He has $\mathrm{PhD}$ in $\mathrm{HCI}$ from Indian Institute of Technology (IIT), Bombay. He is an active member of ACM as well as SIGCHI and is also member of IFIP TC 13, WG 13.6 since 2012. His centre has developed a utility Android app - Eye + for visually impaired users, which was also nominated for National Award in 2018.

Virpi Roto is a Professor of Practice in Experience Design, Aalto University, Finland. She has worked both in industry (Nokia) and academia (Aalto) on user experiences, and is one of the most cited UX researchers. Lately, her research has focused on improving employee experiences during the digital transformation of metal and maritime industry. She is an experienced organizer of workshops at academic conferences, including INTERACT, CHI, and NordiCHI.

Torkil Clemmensen is a Professor at the Department of Digitalization, Copenhagen Business School, Denmark. His research interest is in psychology as a science of design. His research focus on cultural-psychological perspectives on usability, user experience, and digitalization of work. He contributes to Human-Computer Interaction, Design, and Information Systems. He is a co-founder of the HWID working group and has co-organized many workshops and working conferences in this area.

Barbara Rita Barricelli is an Assistant Professor at Department of Computer Science of Università degli Studi di Milano, Italy, where she obtained her PhD in Computer Science. Her research interests are Human-Computer Interaction, End-User Development, Computer Semiotics and Semiotic Engineering, Creative and Participatory 
Design. She has been involved in several International and Italian projects in collaboration with universities, research institutes, and private companies. She is Chair of IFIP TC13's Working Group on Human Work Interaction Design.

Jose Abdelnour-Nocera is Associate Professor in Human Centred Systems at the University of West London, UK. His interests lie in the role of cultural diversity in the design of people-centred systems and in software development teams. In pursuing these interests, he has been involved as researcher and consultant in several projects in the UK and overseas in the domains of international development, mhealth, enterprise resource planning systems, service design and higher education. Dr. Abdelnour-Nocera gained an MSc in Social Psychology from Simon Bolivar University, Venezuela and a $\mathrm{PhD}$ in Computing from The Open University, UK.

Alexander Meschtscherjakov Assistant Professor and deputy director of the Center for Human-Computer Interaction in Salzburg University, Austria. He leads the Car Interaction Lab and member of the senate of Salzburg University. His background is in Computer Sciences. He has co-organized many international workshops and hosted conferences on HCI-related topics. His research is focusing on persuasive interaction technologies for sports and older adults, interface design and evaluation for automotive user interfaces, as well as contextual user experience and challenges of work engagement in the area of automation.

Arminda Guerra Lopes is a professor at Polytechnic Institute of Castelo Branco, Portugal, for twenty five years. She is a research fellow at Madeira Interactive Technologies Institute (M-ITI) in Portugal and, recently, she was visitor professor at Carnegie Mellon University, USA. She teaches human computer interaction, interactive systems design and interactive environments courses. Her research interests are mainly: Human Computer Interaction, Information Systems and Technology for Organizational Agility. She has been working on Interaction Design, Human Work Interaction Design, Creativity and Innovation, and Quality of Life Technologies. She is a vice-chair of the HWID working group.

Pedro Campos is Associate Professor with Habilitation at the University of Madeira, Portugal. Pedro is interested in bridging cognitive augmentation with experience design and exploring novel systems to augment human cognition and to design better user experiences. He has co-organized many international workshops and has also hosted ACM conferences on CHI-related topics, work engagement and automation as well as $\mathrm{CSCW}$.

Frederica Gonçalves, Ph.D., is an Assistant Professor at University of Madeira and Researcher at Madeira-ITI/LARSyS, Portugal. Designing news ways for people have an easier access to reading and writing with novel tools or user interfaces (Creativity Support Tools and HCI) is the main thread of her research. Recently she started investigating new ways to improve tourist experience and also look into novel systems to 
augment human cognition. Previously, she worked as a computer science teacher at higher school. She is member of IFIP TC 13, WG 13.6 since October 2014.

\section{References}

1. Evangelia Demerouti, Daantje Derks, L Lieke, \& Arnold Bakker. (2014). New ways of working: Impact on working conditions, work-family balance, and well-being. In The impact of ICT on quality of working life. Springer, pp. 123-141.

2. Harbich, S., \& Hassenzahl, M. (2008). Beyond task completion in the workplace: Execute, engage, evolve, expand. In Affect and Emotion in Human-Computer Interaction (pp. 154162). Springer, Berlin, Heidelberg.

3. Lindsay G. Oades \& Lara Mossman. (2017). the science of wellbeing and positive psychology. In Wellbeing, Recovery and Mental Health. Cambridge University Press, pp. 723.

4. Millard, N., \& Hole, L. (2008). In the Moodie: Using 'affective widgets' to help contact centre advisors fight stress. In Affect and Emotion in Human-Computer Interaction (pp. 186-193). Springer, Berlin, Heidelberg.

5. Roto, V., Clemmensen, T., Väätäjä, H. \& Law, E. Designing Interactive Systems for Work Engagement. Special issue, Human Technology 14(2), August 2018.

6. Palviainen, J., \& Väänänen-Vainio-Mattila, K. (2009, July). User experience in machinery automation: from concepts and context to design implications. In International Conference on Human Centered Design (pp. 1042-1051). Springer, Berlin, Heidelberg. 